\title{
Isolation, Partial Purification and Characterization of Texas Live Oak (Quercus fusiformis) Lectin
}

\author{
Ruby A. Ynalvez ${ }^{1}$, Carmen G. Cruz ${ }^{1}$, Marcus A. Ynalvez ${ }^{2}$ \\ ${ }^{1}$ Department of Biology and Chemistry, Texas A \& M International University, Laredo, Texas, USA \\ ${ }^{2}$ Department of Social Sciences, Texas A \& M International University, Laredo, Texas, USA \\ Email: ${ }^{*}$ rynalvez@tamiu.edu
}

Received 30 June 2015; accepted 28 July 2015; published 31 July 2015

Copyright (C) 2015 by authors and Scientific Research Publishing Inc.

This work is licensed under the Creative Commons Attribution International License (CC BY). http://creativecommons.org/licenses/by/4.0/

(c) (i) Open Access

\section{Abstract}

Lectins are carbohydrate-binding proteins with agglutination properties. There is a continuous interest in lectins due to their biological properties that can be exploited for medicinal and therapeutic purposes. The objective of this study was to isolate and characterize lectin activity in Texas Live Oak (Quercus fusiformis). More specifically, the study aimed to determine the lectin's blood group specificity and $\mathrm{pH}$ stability, determine effects of seasonal variation, soil moisture and soil pH on lectin activity. The study also aimed to determine the presence of antifungal activity in $Q$. fusiformis extracts. Lectin activity was detected and compared via agglutination and protein assays. Protein partial purification was accomplished using diethylaminoethyl ion-exchange chromatography matrix. High Performance Liquid Chromatography (HPLC) was used to assess purity of the lectin. Results showed that $Q$. fusiformis extracts' lectin activities are stable at a pH range of 5.2 - 9.2 but with a significant decrease in activity above $\mathrm{pH}$ 9.2. The lectin activity was significantly higher when assayed against sheep red blood cells as compared to other blood groups tested. Quercus fusiformis extract is devoid of antifungal activity against Aspergillus niger and Rhizopus stolonifer. The effects of seasonal variation, soil moisture and soil $\mathrm{pH}$ do not significantly correlate with lectin activity. Results from HPLC showed presence of three peaks indicating a partial purification of the $Q$. fusiformis lectin.

\section{Keywords}

Lectin, Quercus fusiformis, Protein Purification, HPLC, Blood Group Specificity, pH Stability

\footnotetext{
"Corresponding author.
}

How to cite this paper: Ynalvez, R.A., Cruz, C.G. and Ynalvez, M.A. (2015) Isolation, Partial Purification and Characterization of Texas Live Oak (Quercus fusiformis) Lectin. Advances in Bioscience and Biotechnology, 6, 470-484. 


\section{Introduction}

Lectin is a protein of non-immunological origin and contains at least one non-catalytic carbohydrate-binding site. Lectins' ability to recognize and specifically bind reversibly to carbohydrates distinguishes them among other proteins [1] [2]. Their capability of specifically recognizing and binding to sugars of erythrocytes in vitro merits the term agglutinin [2] [3], the process is termed agglutination. Lectins' specificities such as binding to glycoprotein receptors on cellular membranes allow the study of the physiological means in cellular communication such as cell-to-cell recognition [4] [5]. Thus, lectins play a pivotal role in cellular communication and protein-carbohydrate interactions [6] [7]. Lectin's sugar-binding property readily distinguishes them as biotechnological tools to define carbohydrate structure and physiological dynamics [8]-[12]. This characteristic is exploited for biomedical research for wide applications [13]-[20]. Sources of lectins within an organism vary from organism to organism. Lectins will also vary in terms of their function, structures, biological activity, concentration, as well as in organ and cellular location [21]-[23].

Isolation and purification of lectins may be done through a variety of protein purification methods [24]-[33]. Methods for purifying lectins vary due to lectin sources (i.e. plant or animal). Methods also will depend on lectins' structure, specificity, physiochemical properties and biological activity [34]. The combinations of methods for lectin purification will vary. For example, in studying seeds of the pepper plant, Capsicum annum lectin was isolated and purified by a four-step procedure [34]. The four-step protein purification procedure for Capsicum annum included lyophilization of samples followed by purification using two column chromatography techniques. The $C$. annum samples were partially purified with two separate columns, DEAE-cellulose and with a second column, QAE-Sephadex. Lastly, partially purified C. annum samples were subjected to affinity column chromatography, using Sephadex G-100 column [34]. Another example was lectin isolation and purification from Artocarpus camansi Blanco seeds, which was a three-step procedure. Blanco seed lectin was isolated with the ammonium sulfate precipitation (salting out) technique. Isolated lectin was then dialyzed and applied to gel-filtration column chromatography using a Sephadex G-200 column [35]. Another method was the extraction of lectin from fresh leaves of Kalanochoe crenata. The lectin was isolated and purified in a two-step procedure, one was ion-exchange column chromatography, DEAE-cellulose and second was gel filtration column chromatography, using Sephadex G-100 [36].

Texas Live Oak (Quercus fusiformis) is a thicket-forming shrub (or a large spreading tree). It is a drought-tolerant and cold-hardy plant compared with its look-a-like Quercus virginiana. The Texas Live Oak is native to Oklahoma and in north central, central and southern Texas [37] [38]. Q. fusiformis belongs to the family Fagaceae and may also be known as Escarpment Live Oak, Plateau Live Oak, Scrub Live Oak and West Texas Live Oak [37]. Several native plant species of Texas have yet to be examined as potential lectin sources, including Texas Live Oak. Previous study reported lectin to be present in the leaf, stem and fruit of $Q$. fusiformis with the highest lectin activity expressed in the leaves [22]. In this regard, the objective of this study was to isolate, partially purify and characterize leaf lectin activity from $Q$. fusiformis. This study focused on conventional methods of protein purification, which included centrifugation and column chromatographic techniques. High Performance Liquid Chromatography (HPLC) assessed the purity of the lectin. The lectin was characterized in terms of its animal blood group specificity, $\mathrm{pH}$ stability, seasonal variation's effect on lectin activity, and soil moisture and soil $\mathrm{pH}$ effect on lectin activity. The antifungal property of the $Q$. fusiformis extract was also determined. The research study was significant since it contributed to the inventory of lectins found in plants. It also established an efficient and effective protocol to isolate and partially purify lectin from Q. fusiformis.

\section{Methodology}

\subsection{Sample Collection}

Leaf samples were collected from Texas Live Oak trees found on the Texas A \& M International University campus. Five trees were selected to sample and represent the Texas Live Oak tree population (N27 $34^{\prime} 24.3^{\prime \prime}$

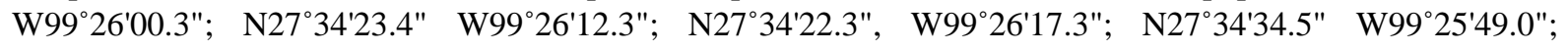
$\left.\mathrm{N} 27^{\circ} 34^{\prime} 23.3^{\prime \prime} \mathrm{W} 99^{\circ} 25^{\prime} 59.1^{\prime \prime}\right)$. Leaf samples collected were mature sized leaves that ranged from 8 centimeter to 12 centimeter in size. Leaf samples were stored in assigned labeled Ziploc ${ }^{\mathrm{TM}}$ bags placed in a $-40^{\circ} \mathrm{C}$ freezer or samples were immediately homogenized. 


\subsection{Crude Extraction}

Leaves were washed, ground and homogenized using a Waring ${ }^{\circledR}$ Laboratory variable-speed blender. Cold 0.01 M Tris-Cl buffer $(0.15 \mathrm{M} \mathrm{NaCl}), \mathrm{pH} 9.4(1: 8 \mathrm{w} / \mathrm{v})$ was added and homogenized for one minute for each respective sample. Samples were stirred for one hour using a VWR ${ }^{\circledR}$ Dyla-Dual ${ }^{\mathrm{TM}}$ Hot Plate Stirrer at $1000 \mathrm{rpm}$ in a cold room $\left(4^{\circ} \mathrm{C}\right)$ to optimize homogenization. Then, the homogenate was filtered using cheesecloth and centrifuged at $8000 \mathrm{rpm}$ at $10^{\circ} \mathrm{C}$ for 30 minutes using an Avanti ${ }^{\circledR} \mathrm{JE}$ Centrifuge JA-20 Rotor. The crude extract was stored $\left(\right.$ at $-40^{\circ} \mathrm{C}$ ) for later use or immediately used for agglutination assays.

\subsection{Preparation of Red Blood Cells}

Two-hundred microliter aliquot of blood samples including human (collected from Laredo Medical Center Laboratory), horse, rabbit and sheep (purchased from Biomérieux ${ }^{\circledR}$ company) were mixed with $10 \mathrm{~mL} 0.01 \mathrm{M}$, phosphate buffer saline (PBS), pH $7.2(0.15 \mathrm{M} \mathrm{NaCl})$ in a $15 \mathrm{~mL}$ tube. The blood suspension was centrifuged at room temperature using a Hamilton Bell ${ }^{\circledR}$ VanGuard V6500 Biohazard centrifuge with fixed speed of $3500 \mathrm{rpm}$ for five minutes. At the end of centrifugation, the supernatant was discarded. A second wash or until the supernatant was clear to remove lysed red blood cells was done using $10 \mathrm{~mL}$ of $0.01 \mathrm{M}$, PBS. The pellet was dissolved with PBS to obtain a $2 \%$ blood suspension.

\subsection{Agglutination Assays}

The crude extract and purified fractions were assayed for the presence of lectin activities using Corningware ${ }^{\mathrm{TM}}$ 96-well microtiter U-plates, 0.01 M PBS and 2\% blood suspension. The sample was diluted by a serial two-fold dilution in PBS (50 $\mu \mathrm{L})$ and incubated with a $2 \%$ suspension of RBCs (50 $\mu \mathrm{L})$ at room temperature for an hour or until the negative control showed a red button formation. Agglutination activity was detected based on the RBCs appearance on the well; a positive result appears as a red-carpet layer, while negative results, appear as a red button in the bottom of the well.

\subsection{Protein Content Determination}

The protein content of crude extract samples was determined with the Bradford method [39] using a QuickStart ${ }^{\mathrm{TM}}$ Bradford Protein Assay Kit.

\subsection{Characterization of Lectin Activities}

\subsubsection{Blood Group Specificity}

The blood group specificity was tested in four different blood groups; horse, human, rabbit and sheep. The animal blood was purchased as defibrinated blood from Biomérieux ${ }^{\circledR}$. Human red blood cells were collected from the Laredo Medical Center Laboratory Department, as postpartum blood samples and screened negative for both HIV and blood-borne communicable diseases.

\subsubsection{Effect of $\mathrm{pH}$ on $Q$. fusiformis Lectin Activity}

Crude extracts of $Q$. fusiformis were studied for the effect of $\mathrm{pH}$ by using buffers of different $\mathrm{pH}$ levels: 5.2, acetate buffer; 6.2 and 7.2 phosphate buffer; 8.2 and 9.2, Tris-Cl buffer.

\subsubsection{Effect of Seasonal Variation on Q. fusiformis Lectin Activity}

Leaf samples were collected in three seasons (fall, winter and summer) to determine if seasonal variation had an effect on Q. fusiformis lectin activity. Summer season consisted of hot temperatures with an average of $104^{\circ} \mathrm{F}$, with mostly clear skies, and long days. The fall season, had an average temperature of $93^{\circ} \mathrm{F}$, with partly cloudy skies and with the most rain due to hurricane season. The winter season consisted of an average temperature of $50^{\circ} \mathrm{F}$, with cloudy skies and short days. Two fall seasons and two winter seasons were observed while only one summer season was observed. Crude extracts of $Q$. fusiformis were prepared with $0.01 \mathrm{M}$ phosphate buffer, 0.15 $\mathrm{M} \mathrm{NaCl}, \mathrm{pH} 7.2$.

\subsubsection{Effect of Soil Moisture on Q. fusiformis Lectin Activity}

The soil samples were collected by the Auger Method. Soil was sampled and subsampled by depth. Soil ex- 
amined was under the Q. fusiformis crown and collected from three Q. fusiformis locations. Q. fusiformis roots are at least 50 centimeters deep [37] [38], thus depth focused on the 20 - 30 centimeter depth, which was the best estimation for soil analysis. Samples were stored in a cold room $\left(4^{\circ} \mathrm{C}\right)$ or used immediately. Soil moisture was determined by examining moisture loss of soil subsamples on aluminum weight trays. Samples were weighed using an analytical balance. A moist, 2.00 gram subsample was used for each triplicate subsample. Soils were oven-baked for 24 hours at $105^{\circ} \mathrm{C}$ to dry and weighed once more to record dry soil mass.

\subsubsection{Effect of Soil $\mathrm{pH}$ on Q. fusiformis Lectin Activity}

Soil samples collected for soil moisture determination were also sampled to determine soil $\mathrm{pH}$. Soil samples were put in paper bags to air-dry for three to seven days, followed by sieving with a two-millimeter (mm) mesh screen \#10. Five g of air-dry soil sample was placed into a $50 \mathrm{~mL}$ labeled centrifuge tube. A total of three replicates were performed. Ten $\mathrm{mL}$ of deionized water was added to the $50 \mathrm{~mL}$ centrifuge tube for a soil water ratio of 1:2. Solutions were shaken for one hour at 120 revolutions per minute (rpm); subsequently, solutions were centrifuged at $15,000-\times \mathrm{g}$ for 5 minutes. The resulting supernatant was used to record $\mathrm{pH}$ using the $\mathrm{VWR}^{\circledR}$ symphony $\mathrm{pH}$ meter.

\subsubsection{Determination of the Antifungal Activity of $Q$. fusiformis Extracts}

Two antifungal assays, an anti-Aspergillus niger and an anti-Rhizopus stolonifer assays were done. Potato Dextrose Agar (PDA) plates were marked with a circular circumference on the bottom of the plate with a 60 millimeter $(\mathrm{mm})$ perimeter. Fungal cultures were grown at $28^{\circ} \mathrm{C}$ until they reached the drawn boundaries which took approximately 24 hours. After the mycelial colony had grown, sterile blank paper discs $(6 \mathrm{~mm}$ in diameter, Grade AA) were saturated with $20 \mu \mathrm{L}$ aliquot solutions of $Q$. fusiformis freeze-dried crude extracts that were diluted with sterile water. The concentrations, $125 \mu \mathrm{g} / \mu \mathrm{l}, 250 \mu \mathrm{g} / \mu \mathrm{l}$ and $500 \mu \mathrm{g} / \mu \mathrm{l}$ were tested. The discs were placed at the outer rim of the mycelial colony (which was within the new circumference of $60 \mathrm{~mm}$ away from the original circumference of the petri plate). The plates were incubated at $28^{\circ} \mathrm{C}$ for 24 hours. After incubation, crescents or zones of inhibition were measured using a vernier caliper. A negative control was used (sterile water) which allowed mycelial growth. On the other hand, a positive control (nystatin) was used to demonstrate the formation of crescents or zones of inhibition around the disc (Figure 1).

\subsection{Purification of $Q$, fusiformis Lectin}

The lectin from $Q$. fusiforms crude extracts was partially purified by one step chromatography using an ion-exchange column chromatography with a Bio-Rad ${ }^{\circledR}$ BioLogic ${ }^{\mathrm{TM}}$ low-pressure chromatography system. All absorbance readings were at $280 \mathrm{~nm}$. The flow rate was $1 \mathrm{ml} / \mathrm{min}$ and collections of eluate with $3 \mathrm{~mL} /$ fraction. Twenty-six $\mathrm{mL}$ of $\mathrm{Q}$. fusiformis crude extract was applied to DEAE-cellulose column, which was equilibrated and washed with Buffer A, $0.01 \mathrm{M}$ Trizma-Cl with $0.15 \mathrm{M} \mathrm{NaCl}$, pH 9.2. After washing, Buffer B, $0.01 \mathrm{M}$ Trizma-Cl with $0.5 \mathrm{M} \mathrm{NaCl}$, $\mathrm{pH}$ 9.2, was run into the column until absorbance was below $<0.01$, then elution Buffer $\mathrm{C}, 0.01$ M Trizma-Cl with $1.0 \mathrm{M} \mathrm{NaCl}, \mathrm{pH}$ 9.2, was applied into the column. A Bio-Rad ${ }^{\circledR}$ fraction collector

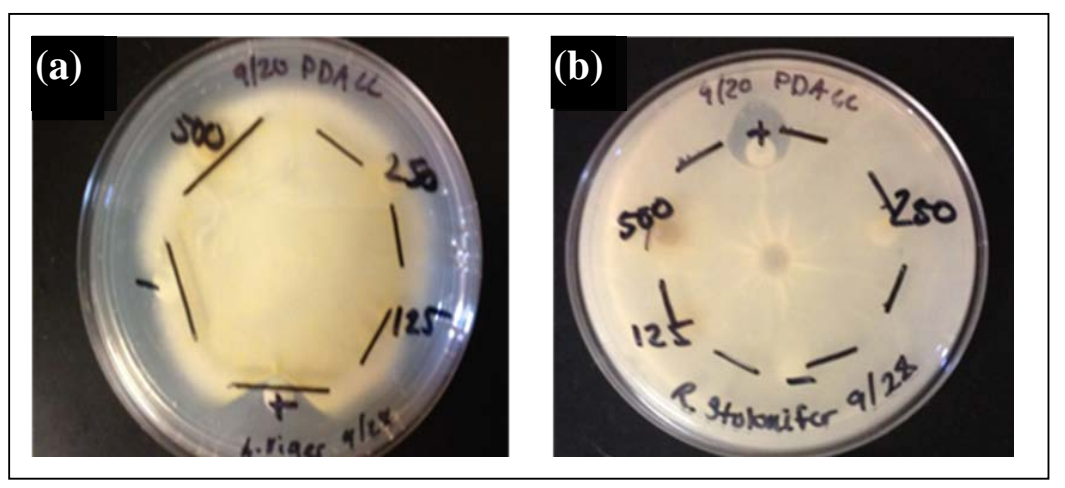

Figure 1. Antifungal activity assay against (a) A. niger and (b) $R$. stolonifer. The negative control was sterile water and the positive $(+)$ control was the antifungal agent, nystatin showing crescent and zone of inhibition for $A$. niger and $R$. stolonifer, respectively. 
(\#731 - 8304) was used to collect fractioned proteins. Fractioned proteins were pooled and dialyzed to remove the salts. Dialysis was performed with Thermo Scientific SnakeSkin ${ }^{\circledR}$ dialysis tubing. The dialysate used was deionized water. The dialyzed samples were then freeze-dried.

High Performance Liquid Chromatography (HPLC) separation was performed on Prostar PS 220 system which has a UV detector and Rheodyne injector with $20 \mu$ loop volume. Galaxie ${ }^{\odot}$ Software was applied for data collecting and processing. Purity assessment of the dialyzed and freeze-dried sample ( $2 \mu \mathrm{L}$ of freeze-dried sample diluted in $100 \mu \mathrm{L}$ deionized $\left.\mathrm{H}_{2} \mathrm{O}\right)$ was analyzed by HPLC. A Phenomenex RP-C18 $(250 \times 4.60 \mathrm{~mm})$ column was used as the stationary phase. A gradient of $100 \%$ water to $100 \%$ methanol was used as mobile phase. The mobile phase was pumped at $1 \mathrm{ml} / \mathrm{min}$ and the eluents were monitored at $215 \mathrm{~nm}$ and $280 \mathrm{~nm}$. The injection volumes of samples were $20 \mu \mathrm{l}$.

\subsection{Statistical Analysis}

Data for blood group specificity and $\mathrm{pH}$ stability were obtained from five replicates. An analysis of variance (ANOVA) associated with a $5 \times 4$ factorial experiment in randomized complete blocks design was performed using the Statistical Analysis System (SAS 9.3) ${ }^{\circledR}$ software. Mean comparisons were performed by way of a Bonferroni test using a type I error rate of 0.05. Data analysis for seasonal variation was carried out using a one-way ANOVA. Bivariate correlations among seasonal variation, soil moisture and $\mathrm{pH}$ were estimated and tested using a Pearson correlation analysis with level of significance for a two-tailed test set at 0.01 .

\section{Results and Discussion}

Lectin activity from $Q$. fusiformis leaves was investigated, using agglutination assays. In the presence of lectin, sugars on the surface of red blood cells form an interaction with the lectin resulting in agglutination. This is evident by the formation of a carpet layer on the bottom of a microtiter plate wells. On the other hand, in the absence of lectin, a distinctive red button is formed on the bottom of the microtiter plate well. The reciprocal of dilution is calculated as titer value, which reflects lectin activity. The higher the titer value the higher is the lectin activity. Different factors i.e. blood group specificity; $\mathrm{pH}$ and seasonal variation are known to affect lectin activities [40]-[43]. In this study, how these factors affect $Q$. fusiformis lectin activity were investigated. Results of the study will aid in the characterization of $Q$. fusiformis lectin.

\subsection{Blood Group Specificity Study of $Q$. fusiformis Lectin}

The blood group specificity of Q. fusiformis lectin activity was investigated in four blood groups (horse, human, rabbit and sheep). The extracts of Q. fusiformis agglutinated to all blood groups tested, making $Q$. fusiformis a non-blood group specific lectin. Lectin specific activity (SA) was expressed as titer over milligrams of protein. For analysis, lectin specific activity was transformed to natural logarithm of specific activity (ln SA). ANOVA results reported a difference among the four blood groups tested, which was subjected to a Bonferroni test using a Type I error rate ( $\alpha$ of 5\%) for mean comparisons to determine significant differences (Table 1, Figure 2). The Bonferroni test showed a significant difference in the ln specific activity values of $Q$. fusiformis lectin between

Table 1. Determinations of blood group specificity of $Q$. fusiformis crude extract lectin.

\begin{tabular}{cccccc}
\hline Blood group & Titer $^{\mathrm{a}}$ & Protein Content(mg/mL) $^{\mathrm{b}}$ & HA $^{\mathrm{c}}$ & \multicolumn{2}{c}{${\text { SA }\left(\mathrm{titer} / \mathrm{mg}^{\mathrm{d}}\right.}^{\operatorname{lnSA}^{\mathrm{e}}}$} \\
\hline Horse & 6.08 & 0.743 & 304 & 959.59 \\
Human & 18.16 & 0.743 & 908 & $7.29^{\mathrm{f}}$ & 2094.11 \\
Rabbit & 15.2 & 0.743 & 760 & 2542.26 \\
Sheep & 49.44 & 0.743 & 2472 & $10,654.62$ \\
\hline
\end{tabular}

\footnotetext{
${ }^{a}$ Titer is the reciprocal of the lowest dilution that was positive for lectin activity.

${ }^{\mathrm{b}}$ Protein content was determined using Bradford assay.

${ }^{\mathrm{c}}$ Hemagglutination Activity (HA), is titer multiplied with sample volume (50 uL).

${ }^{\mathrm{d}} \mathrm{SA}$, Specific Activity is HA divided by the protein content.

${ }^{\mathrm{e}}$ ln Specific activity (SA), is the natural logarithm of specific activity. Values of ln SA are mean values from Bonferroni test using a type I error rate of $5 \%$.

${ }^{\mathrm{f}}$ Blood groups horse, human and rabbit show no significant difference from each other.

${ }^{\mathrm{g}}$ Sheep blood group is significantly different from horse, human and rabbit.
} 


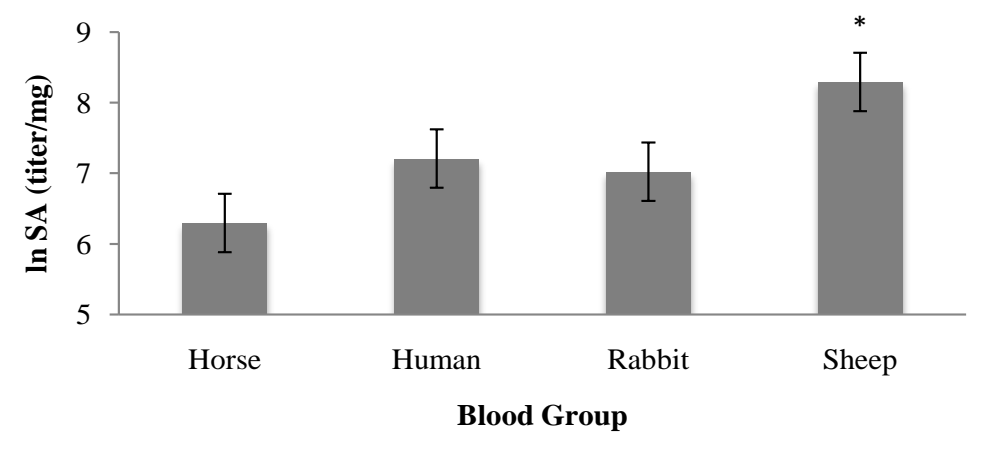

*Significant $(\mathrm{p}<0.05)$ compared to horse, human and rabbit blood groups.

Figure 2. Blood group specificity of $Q$. fusiformis lectin based on ln SA of mean comparisons analyzed with a Bonferroni test using a type I error rate of $5 \%$.

sheep blood (ln SA = 8.30) and the three blood groups (horse, $\ln S A=6.29$ ), human (ln $S A=7.21$ ) and rabbit (ln $\mathrm{SA}=7.02$ ). As shown in Figure 2, ln specific activity using sheep blood showed a significantly higher lectin activity as compared to the other three blood groups. However, lectinln specific activities of $Q$. fusiformis using horse, human and rabbit blood groups were not significantly different from each other.

Specificity is influenced by the limited number of contacts with carbohydrates and depth of the sugar binding sites [44]. In addition, any modification or substitution to a binding site can influence binding specificity [45]. The observed differences in $Q$. fusiformis lectin activity with different blood groups may be due to differences in carbohydrate-lectin binding interactions which can be attributed to differences in carbohydrates presented on the cell surfaces of the different blood groups.

The carbohydrates on the erythrocyte cellular surfaces are distinguishable among the four different blood groups [46]. There are reported monosaccharide determinants in the different blood groups, fucose in horse [47], galactose in human and [47]-[49] and mannose in rabbit erythrocytes [50]. Horse, human and rabbit red blood cells may contain carbohydrate components on the cellular surface binding sites that are relatively less recognized by the $Q$. fusiformis lectin binding site. On the other hand, the carbohydrates found on the cellular surface of sheep red blood cells may contain carbohydrate units in a structure and position more specific and with higher affinity for the binding of $Q$. fusiformis lectin, subsequently increasing sheep erythrocyte agglutination. Moreover, lectin characteristics such as, multivalency may determine cross-linking interaction in binding recognition. Spatial distribution of multivalency among lectin structures may produce a higher level of specificity [51] [52].

Quercus fusiformis lectin activity is similar to other plant lectins that are also non-blood group specific. Erythrina speciosa lectin was characterized as a non-blood group specific. Its lectin activity was examined in the human blood ABO system and animal blood groups, rabbit, mouse, sheep and horse [53]. Likewise, the blood group specificity for leaf lectin in Kalanochoe crenata was characterized as a non-blood group specific lectin, agglutinating to the different types of human blood red cells of the ABO system [36]. Artocarpus incisa seeds were also examined in a wide range of blood groups including human ABO system and animal blood groups, cow, goat, rabbit, pig and sheep. Artocarpus incisa seed lectin resulted in non-blood group specificity in humans ABO system, while rabbit blood group activity was not different from human ABO and the other four blood groups were significantly different from human and rabbit agglutination [54]. Similarly, Bryopsis plumosa lectin from a green marine alga agglutinated sheep and horse erythrocytes [55]. The blood group specificity of $Q$. fusiformis lectin activity suggests $Q$. fusiformis lectin is non-blood group specific with higher specificity directed towards sheep erythrocytes. The present study is the first to report the non-blood group specificity of the $Q$. fusiformis lectin.

\subsection{Effect of $\mathrm{pH}$ on Q. fusiformis Lectin Activity}

Crude extracts of $Q$. fusiformis lectin were prepared and incubated in wide range of $\mathrm{pH}$ values with stirring for 24 hours at $4{ }^{\circ} \mathrm{C}$. A Bonferroni test using a Type I error rate ( $\alpha$ of 5\%) was used to compare mean natural logarithm-transformed specific activity (ln SA) across pH levels (5.2, 6.2, 7.2, 8.2 and 9.2). Results indicated that $Q$. fusiformis lectin was stable at a $\mathrm{pH}$ range 5.2 to 8.2 while that for $\mathrm{pH} 9.2$ was significantly lower than at $\mathrm{pH} 5.2$ 8.2 (Table 2, Figure 3). Different $\mathrm{pH}$ conditions were found to have profound effects on the tertiary and qua- 
Table 2. Effect of $\mathrm{pH}$ on Q. fusiformis crude extract lectin.

\begin{tabular}{cccccc}
\hline $\mathrm{pH}$ & Titer $^{\mathrm{a}}$ & Protein Content $(\mathrm{ug} / \mathrm{uL})^{\mathrm{b}}$ & HA $^{\mathrm{c}}$ & SA(titer/mg) & lnSA $^{\mathrm{d}}$ \\
\hline 5.2 & 18.6 & 0.532 & 930 & 2912.27 & $7.33^{\mathrm{f}}$ \\
6.2 & 19.8 & 0.697 & 990 & 3053.03 & $7.25^{\mathrm{f}}$ \\
7.2 & 36.1 & 0.856 & 1805 & 8147.53 & $7.73^{\mathrm{f}}$ \\
8.2 & 24.5 & 0.78 & 1225 & 4944.42 & $7.32^{\mathrm{f}}$ \\
9.2 & 12.5 & 0.847 & 607 & 1255.98 & $6.39^{\mathrm{g}}$ \\
\hline
\end{tabular}

${ }^{\mathrm{a}}$ Titer is the reciprocal of the lowest dilution that was positive for lectin activity.

${ }^{\mathrm{b}}$ Protein content was determined using Bradford assay.

${ }^{\mathrm{c}}$ Hemagglutination Activity (HA), is titer multiplied with sample volume (50 $\mu \mathrm{L}$ ).

${ }^{\mathrm{d}} \mathrm{SA}$, Specific Activity is HA divided by the protein content.

${ }^{\mathrm{e}}$ ln Specific activity (SA), is the natural logarithm of specific activity. Values of ln SA are mean values from Bonferroni test using a type I error rate of $5 \%$.

${ }_{\mathrm{f}}^{\mathrm{pH}}$ levels not significant difference from each other, lectin activity was stable.

${ }^{\mathrm{g}} \mathrm{pH}$ level significantly different from $5.2-9.2$

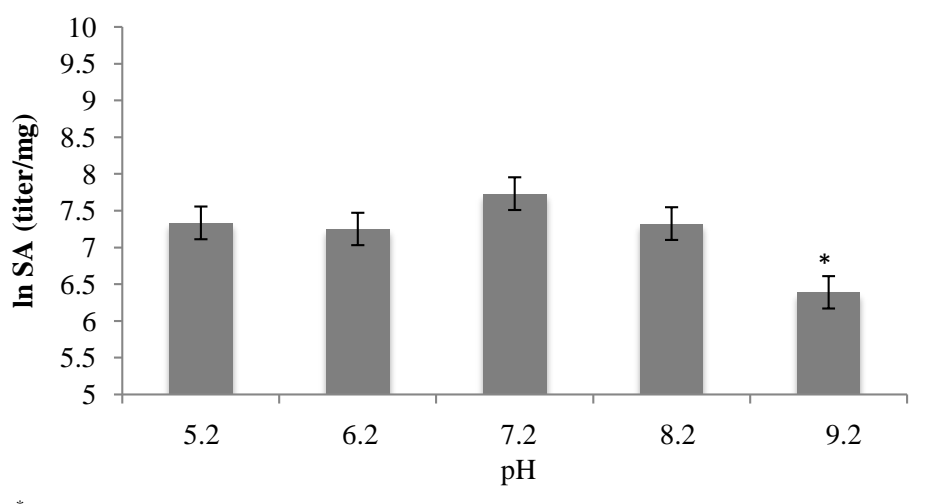

*Significant, $(\mathrm{p}<0.05)$ compared to $\mathrm{pH}$ range of 5.2 - 8.2.

Figure 3. The effect of $\mathrm{pH}$ on Q. fusiformis lectin activity based on mean comparisons of ln SA analyzed with a Bonferroni test using a 5\% type-I error rate.

ternary structure of proteins and can perturb protein conformational stability [36] [56]. Lectins have different optimum $\mathrm{pH}$ to maintain their stabilities [57].

Literature reported that $\mathrm{pH}$ stabilities of plant lectins vary. For example, Morus rubra [58] and Ipomoea asarifolia [59] leaf lectin crude extracts were stable at $\mathrm{pH}$ 7.5, while the Korean mistletoe lectin crude extract was stable at $\mathrm{pH} 8.0$ [60]. On the other hand, the $\mathrm{pH}$ stability of Kalanochoe crenata leaf lectin was at $\mathrm{pH}$ values 2 to 12 [36]. Kalanochoe crenata leaf lectin activity was stable from $\mathrm{pH} 2$ to 7.5, and the activity was lost at a pH higher than 9.2 [36]. The effect of $\mathrm{pH}$ on lectin activity was studied in the leaves of Chorchorus olitours also in a broad range of $\mathrm{pH}$ values from $\mathrm{pH} 2.0$ to 10.5. Chorchorus olitours exhibited a high agglutination activity from $\mathrm{pH} 7.2$ to 8.0 with a dramatic decrease of lectin activity below acidic conditions of $\mathrm{pH} 6.5$ and above basic $\mathrm{pH}$ of 9.0 [46]. The $\mathrm{pH}$ stability of $Q$. fusiformis lectin activity at a wide range of $\mathrm{pH}$ is quite similar to other leaf lectins.

\subsection{Effect of Seasonal Variation on $Q$. fusiformis Lectin Activity}

Previous studies have reported lectin sources that display a seasonal variation in lectin activity [61]. For example, Elderberry (Sambucus nigra) and Black locust (Robinia pseudoacacia) bark lectins demonstrated a seasonal variation in content where lectin accumulation was higher during summer to winter compared to spring [42]. On the other hand, lectin activities in cultivated red alga (Kappaphycus alvarezii) varied with environmental characteristics such as heavy rain, solar radiation and low seawater temperatures [61]. It was hypothesized that lectin fluctuation found in both Elderberry and Black locust barks as contributed by seasonal variation resembles the behavior of plant storage proteins [42]. Although, many plant lectins mimic the behavior of plant storage proteins, these lectins should not be classified as storage proteins [2]. Costa et al. [43] studied Phthirusa pyrilfo- 
lia leaf lectin activity with an activity higher during sunny weather. This was attributed to mistletoe's slower rate of photosynthesis promoting high lectin production.

In this study, Q. fusiformis leaf samples were collected during the fall, winter and summer seasons and lectin activities were compared. The mean ln SA (specific activity) was 7.6, 7.8 and 8.2 for fall, winter and summer, respectively (Table 3). Results of the correlation analysis determined that there was no significant correlation in mean ln SA for Q. fusiformis lectin during the different seasons, fall, winter and summer (Figure 4). Compared to previous studies, this study has shown that $Q$. fusiformis lectin activity was not affected by seasonal variations.

\subsection{Effect of Soil Moisture and Soil pH on Q. fusiformis Lectin Activity}

Since the productivity of plants including biomolecule synthesis is affected by environmental factors, soil properties, moisture and $\mathrm{pH}$ were examined to determine if any of these factors affect lectin activity in Q. fusiformis. To date, the literature with regards to soil properties namely, moisture and $\mathrm{pH}$ affecting lectin activity are scarce. The lectin activity of common beans (Phaseolus vulgaris) was examined in three different soil types in a semiarid region. The result of this study reported differences in lectin concentration and suggested environmental factors to contribute to lectin difference [62]. Results of the present study showed the average soil $\mathrm{pH}$ reading for 20 - 30 centimeter depth in fall was $\mathrm{pH} 8.36$ and in winter was $\mathrm{pH}$ 8.31. On the other hand, the average moisture loss for the 20 - 30 centimeter depth in fall was $3 \%$ and for winter $5.6 \%$.

The soil moisture and $\mathrm{pH}$ were subjected to a correlation analysis with level of significance for a two-tailed test at level 0.01 as shown in Table 4. Soil moisture and $\mathrm{pH}$ reflect the chemical status of soil conditions for the Q. fusiformis. Laredo soil is usually alkaline throughout [63]. Since the $\mathrm{pH}$ results of soil are basic, this may indicate that there may be some nutrients unavailable to $Q$. fusiformis, the production and expression of lectin may be affected. On the other hand, $Q$. fusiformis is a drought-tolerant tree and only requires water every three to

Table 3. Effect of seasonal variation of $Q$. fusiformis crude extract lectin.

\begin{tabular}{ccccc}
\hline Seasons & Titer $^{\mathrm{a}}$ & Protein Content $^{\mathrm{b}}$ & HA $^{\mathrm{c}}$ & SA (titer/mg) $^{\mathrm{d}}$ \\
Fall & 5 & 0.15683 & 200 & 2540.06 \\
Winter & 9 & 0.165167 & 450 & 2792.97 \\
Summer & 4 & 0.112667 & 200 & 3.67675 \\
\hline
\end{tabular}

${ }^{a}$ Titer is the reciprocal of the lowest dilution that was positive for lectin activity.

${ }^{\mathrm{b}}$ Protein content was determined using Bradford assay.

${ }^{\mathrm{c}}$ Hemagglutination Activity (HA), is titer multiplied with sample volume (50 uL).

${ }^{\mathrm{d}} \mathrm{SA}$, Specific Activity is HA divided by the protein content.

${ }^{\mathrm{e}}$ In Specific activity (SA), is the natural logarithm of specific activity. Values of $\ln$ SA are mean values from one-way ANOVA, t-test.

Table 4. Pearson correlation analysis for the effect of soil moisture and soil $\mathrm{pH}$ on lectin activity of Q. fusiformis.

\begin{tabular}{|c|c|c|c|c|c|}
\hline & & $\ln \mathrm{SA}$ & SA & soil moisture 20 - $30 \mathrm{~cm}$ & soil pH 20 - $30 \mathrm{~cm}$ \\
\hline & Correlation & 1 & 0.972 & $0.454^{* *}$ & $0.479^{* *}$ \\
\hline \multirow[t]{3}{*}{$\ln \mathrm{SA}$} & Sig. (2-tailed) & & 0.000 & 0.089 & 0.071 \\
\hline & $\mathrm{N}$ & 15 & 15 & 15 & 15 \\
\hline & Correlation & 0.972 & 1 & $0.432^{* *}$ & $0.442^{* *}$ \\
\hline \multirow[t]{3}{*}{ SA } & Sig. (2-tailed) & 0.000 & & 0.108 & 0.099 \\
\hline & $\mathrm{N}$ & 15 & 15 & 15 & 15 \\
\hline & Correlation & $0.454^{* *}$ & $0.432^{* *}$ & 1 & 0.844 \\
\hline \multirow[t]{3}{*}{ soil moisture 20 - $30 \mathrm{~cm}$} & Sig. (2-tailed) & 0.089 & 0.108 & & 0.000 \\
\hline & $\mathrm{N}$ & 15 & 15 & 15 & 15 \\
\hline & Correlation & $0.479^{* * *}$ & $0.442^{* *}$ & 0.844 & 1 \\
\hline \multirow[t]{2}{*}{ soil pH $20-30 \mathrm{~cm}$} & Sig. (2-tailed) & 0.071 & 0.099 & 0.000 & \\
\hline & $\mathrm{N}$ & 15 & 15 & 15 & 15 \\
\hline
\end{tabular}

${ }^{* *}$ Correlation is significant at the level 0.01 (2-tailed). 


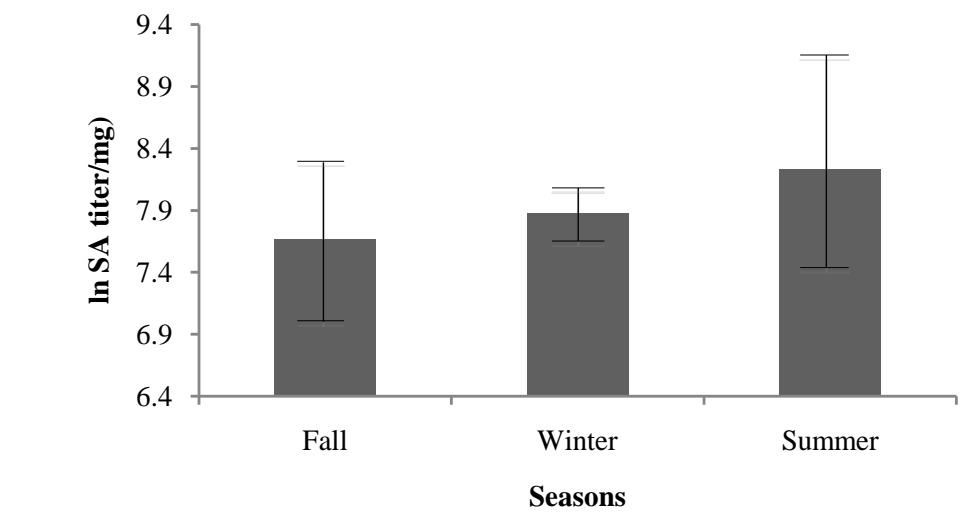

Figure 4. Seasonal variation results from correlation analysis of lectin mean ln SA.

four weeks. Analysis of the results for soil moisture and soil $\mathrm{pH}$ showed no significant correlation with ln SA for Q. fusiformis lectin.

\subsection{Determination of the Antifungal Activity of $Q$. fusiformis Extracts}

There are two physiological proposed roles for plant lectins; the first is in plant defense mechanisms and the second, symbiotic nitrogen-fixing bacteria association [7] [64] [65]. Plant lectins have been investigated for their resistance to insects [66], bacteria [1] [27] [67] [68] and fungi [1] [2] [69] [70]. The study of Q. fusiformis lectin is relevant since new compounds and especially plant lectins with antifungal activity are of high interest due to rising fungal resistance to common fungicides. There are only a few plant lectins reported to have antifungal activities.

The antifungal activity of Q. fusiformis lectin was tested against Aspergillus niger and Rhizopus stolonifer. These two fungi are common pathogens in fruits and vegetables and cause rot disease [71]. Freeze-dried crude extracts of $125 \mu \mathrm{g} / \mu \mathrm{l}, 250 \mu \mathrm{g} / \mu \mathrm{l}$ and $500 \mu \mathrm{g} / \mu \mathrm{l}$ concentrations did not show any antifungal activity against $A$. niger and $R$. stolonifer. Similarly, the knife bean (Canavalia gladiata) lectin, was devoid of antifungal activity when tested against three fungi Botrytis cinerea, Myocospharella arachidcola and Fusarium oxysporum [72]. In contrast, plant mistletoe (Phthirusapyrfolia) lectin was tested against eleven fungi (Aspergillus niger, A. flavus, A. fumigatus, Rhizopus arrhizue, Paeciloyces variottie, Fusarium moniliforme, F. laterituium, Candida albicans, C. burneses, C. tropicalis, C. parapsilosis, Saccharomyces cerevisiae and Rhizoctnia solani) and demonstrated antifungal activity against two fungi $F$. lateritium and $R$. solani [43]. Red kidney bean (Phaseolus vulgaris)lectin reported by Ye et al. [73], also expressed antifungal activity but towards three fungal species, Fusarium oxysporum, Rhizoctonia solani and Coprinus comatus.

\subsection{Purification of $Q$. fusiformis Lectin}

The crude extraction of lectin from Q. fusiformis was achieved by homogenization in Tris-Cl, pH 9.2 (0.15 M $\mathrm{NaCl}$ ) buffer and stirred at $4^{\circ} \mathrm{C}$ for one hour. Partial purification of $Q$. fusiformis crude extract was carried out by a one-step column chromatography technique using the ion-exchange chromatography column. The weak anionic DEAE-cellulose column (Pall Life Sciences AcroSep ${ }^{\mathrm{TM}}$, Product No. 20067-C001) consisted of a matrix with positive charges that will bind negatively charged proteins. Crude extracts of $Q$. fusiformis at $\mathrm{pH} 9.2$ ran through the DEAE column chromatography resulted in the binding of proteins. The chromatography profile showed three peaks, peaks are labeled with abbreviation letter D to indicate DEAE. As shown in Figure 5, the $Q$. fusiformis crude extract resulted in the separation of proteins that corresponded to 3 peaks. The first peak (D1), the major peak, contained unbound proteins. The second peak (D2) and third peak (D3) corresponded to bound proteins that were eluted from the DEAE column using half stepwise salt concentration gradient 0.5 and $1.0 \mathrm{M}$, respectively.

Quercus fusiformis DEAE fractions, D1, D2 and D3 were tested for agglutination activities. These fractions did not exhibit any agglutinating activity. The absence of lectin activity in DEAE fractions may be for two reasons. First, fractions may not contain enough lectin concentration to have an activity detectable by the sensitivity of the agglutination assay due to dilution effect of column chromatography. Secondly, the high salt concentra- 
tion used to elute proteins in peaks D2 and D3 may indicate an effect on conformational structure and stability of the lectin. Thus, fractions from each peak were pooled, dialyzed and lyophilized. Dialyzed samples were measured for $\mathrm{pH}$ with litmus paper and demonstrated a neutral $\mathrm{pH}$.

Lectin activity is affected when $\mathrm{pH}$ conditions are modified for basic or acidic conditions [57]. This is true for Q. fusiformis lectin activity, and provides support for the effect of $\mathrm{pH}$ results when lectin activity decrease at $\mathrm{pH}$ level 9.2. The lyophilized samples were diluted with $200 \mu \mathrm{l}$ of millipore water and subjected to agglutination assays to detect presence of lectin activity. Table 5 shows results of the agglutination assays. Results showed that all peaks contained lectin activity. The binding of $Q$. fusiformis lectin to the DEAE column could be attributed to the lectin amino acid composition. It can be assumed that $Q$. fusiformis lectin has a predominance of negatively charged aspartic acid and/or glutamic acid residues. These amino acids would give the lectin a net negative charge at the basic $\mathrm{pH}$ due to the R-carboxylic groups ( $\left.\mathrm{COO}^{-}\right)$present. Thus, the negatively charged $Q$. fusiformis lectins bind to the positive charged matrix of DEAE. For example, red marine alga (Vidalia obtusilo$b a$ C.) lectin was purified through two chromatographic steps, with its first step being an ion exchange DEAEcellulose column. This lectin was reported to be rich in aspartic acid, glutamic acid and leucine [74].

\subsection{Determination of Q. fusiformis Purity via HPLC}

The first peak, D1 contained all unbound proteins including unbound lectins, thus D1 was not subjected to purity determination. Between D2 and D3, D2 was chosen for purity determination owing to the relatively higher protein concentration as well as higher lectin activity observed in peak 2, D2. The purity of sample D2 was assessed using high performance liquid chromatography (HPLC). Based on the analytical assessment of D2, Q. fusiformis

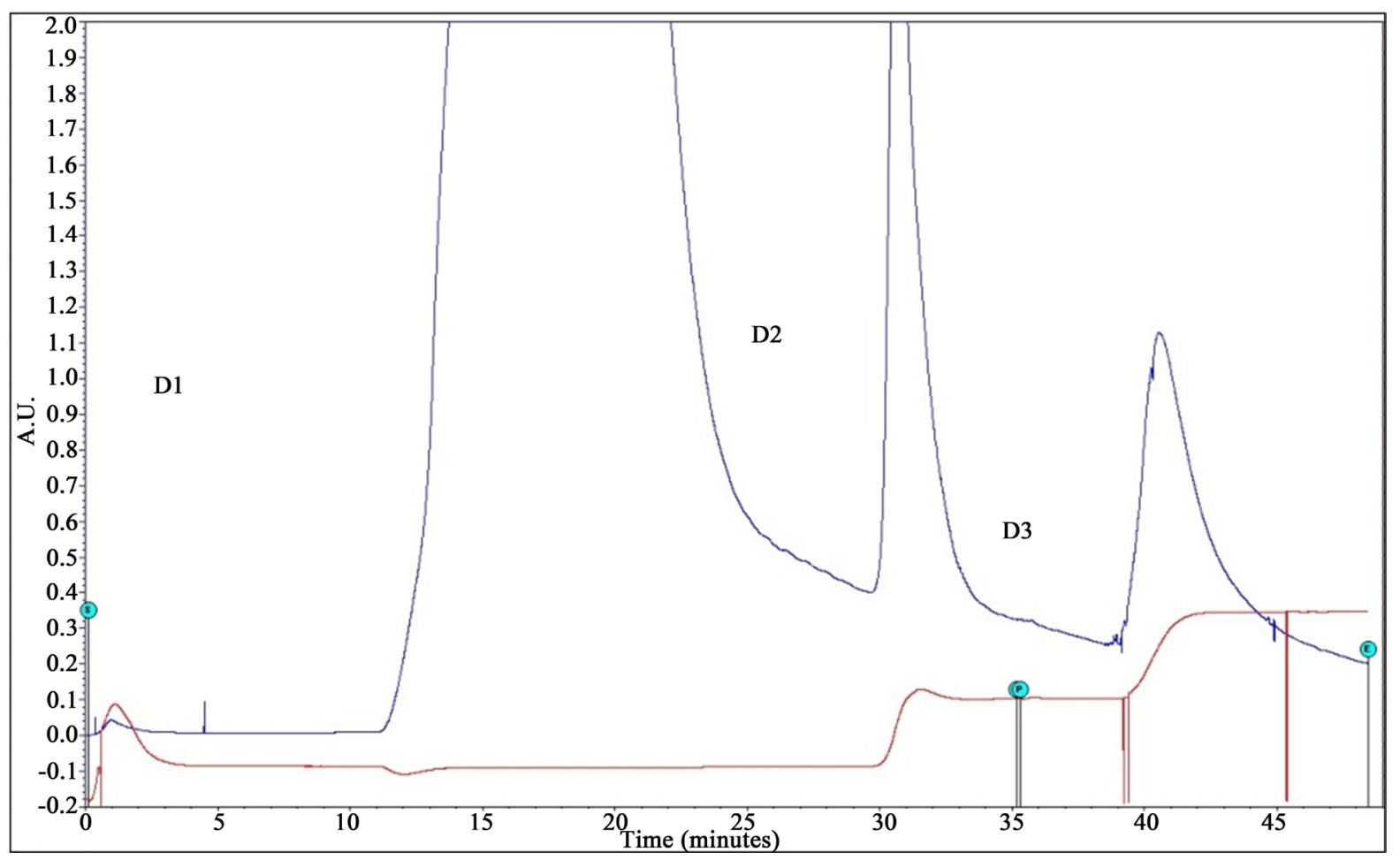

Figure 5. Purification of $Q$. fusiformis lectin by DEAE ion-exchange column chromatography.

Table 5. Lectin activity of the dialyzed and lyophilized fractions from D1, D2 and D3.

\begin{tabular}{ccc}
\hline Peak & Titer & HA \\
\hline D1 & 144 & 7200 \\
D2 & 20 & 1000 \\
D3 & 10 & 500 \\
\hline
\end{tabular}




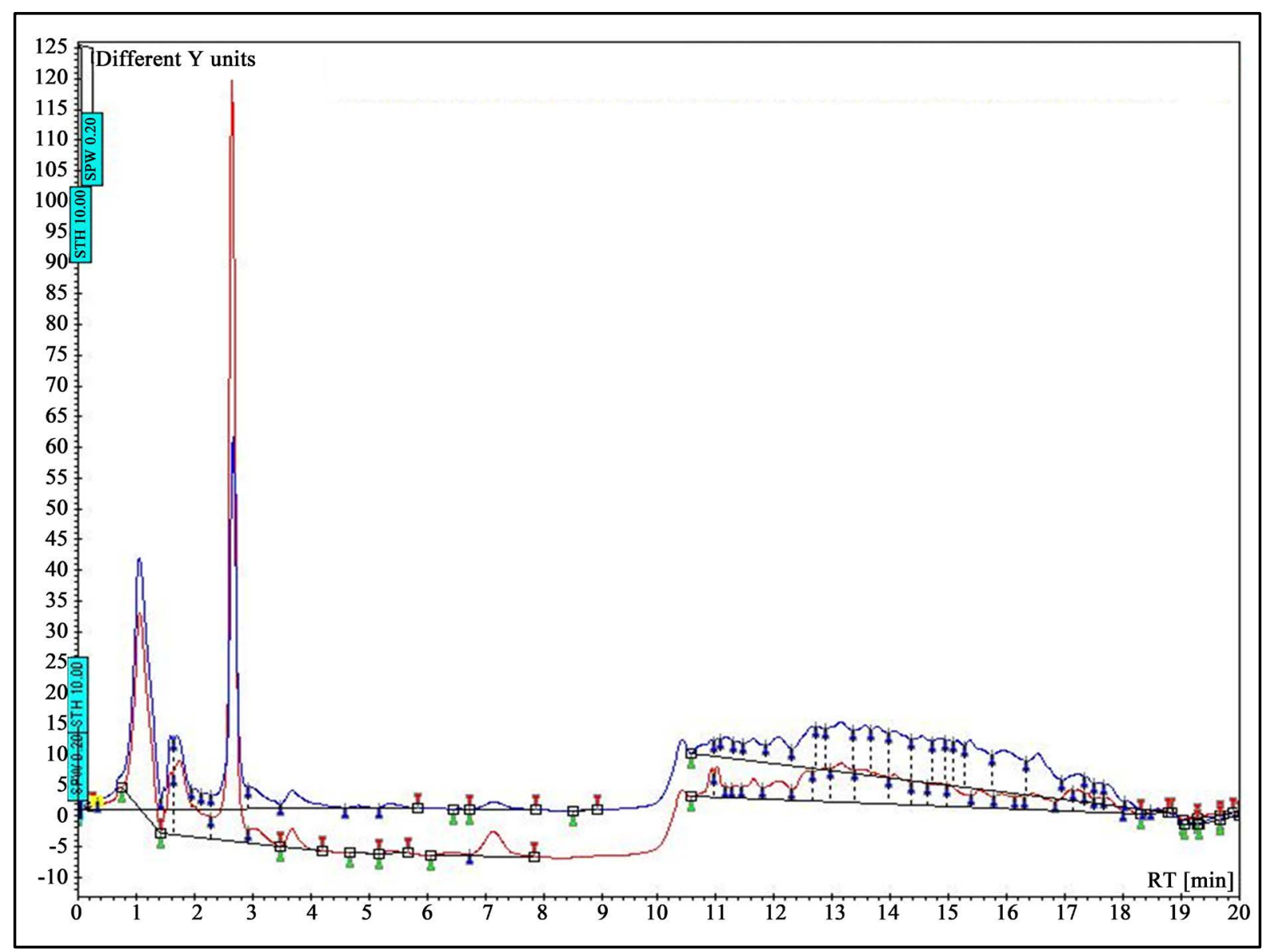

Figure 6. HPLC elution profile of peak 2, D2 from DEAE ion exchange column chromatography of Q. fusiformis extract showed three peaks.

lectin is either only partially purified or D2 contains at least three isolectins since 3 peaks (retention times, 1.0, 1.5 and $2.5 \mathrm{~min}$ ) were obtained after HPLC (Figure 6). Isolectins are defined as closely related lectins difficult to separate since they have a similar amino acid composition.

\section{Conclusions}

Quercus fusiformis' lectin was non-blood group specific, with significantly higher affinity for sheep blood. Also, Q. fusiformis lectin was stable within a $\mathrm{pH}$ range of $\mathrm{pH} 5.2$ to 8.2, with optimal activity at 7.2 and a significant decrease in activity at $\mathrm{pH}$ 9.2. The $\mathrm{pH}$ sensitivity of $\mathrm{Q}$. fusiformis lectin indicates that the three-dimensional conformational structure and its binding sites are disrupted by ionic interactions occurring in different buffers and $\mathrm{pH}$ values. Seasonal variation was examined and no significant difference was found in lectin activity in $Q$. fusiformis. Environmental factors examined in this study focused on soil properties, soil moisture and $\mathrm{pH}$. These soil properties had no significant effect on lectin activity in Q. fusiformis. Lectin is hypothesized to play a role in plant defense and exhibit antifungal properties. Crude extracts from $Q$. fusiformis were examined for antifungal activity for potential inhibition and was devoid of fungal activity in the two fungi tested, A. niger and R. stolonifer.

The one step ion-exchange column chromatography technique with DEAE column resulted in two adsorbed peaks, with lectin activities. HPLC results indicated a partially purified lectin. Results of the present study provide a characterization and the partial purification of $Q$. fusiformis lectin. Future efforts are needed that include upscale purification and further characterization of the lectin under study. The sugar inhibition test may reveal sugar specificity of $Q$. fusiformis lectin. Highly concentrated lectin and purified lectin may be examined for other biological activities including antifungal activities. In addition, determination of antifungal activities against other fungal species is recommended. The DEAE isolate can be further purified using a galactose affinity col- 
umn owing to Q. fusiformis observed affinity to sheep’s blood.

\section{Acknowledgements}

The Avanti JE Centrifuge was acquired through a U.S. National Science Foundation Major Research Instrument grant award (DBI 0959395). This research was funded by a Texas A \& M International University Research Development Award to R. A. Ynalvez. The authors would like to thank Dr. A. Addo-Mensah for the technical advice on the use of the HPLC.

\section{References}

[1] Charungchitrak, S., Petsom, A., Sangvanich, P. and Karnchanatat, A. (2011) Antifungal and Antibacterial Activities of Lectinfrom the Seeds of Archidendron jiringa Nielsen. Food Chemistry, 126, 1025-1032. http://dx.doi.org/10.1016/j.foodchem.2010.11.114

[2] Peumans, W.J. and Van Damme, E.J.M. (1995) Lectins as Plant Defense Proteins. Plant Physiology, 109, $347-352$. http://dx.doi.org/10.1104/pp.109.2.347

[3] Hajtó, T., Hostanska, K., Berki, T., Pálinkas, L., Boldizsár, F. and Németh, P. (2005) Oncopharmacological Perspectives of a Plant Lectin (Viscum Album Agglutinin-I): Overview of Recent Results from in-Vitro Experiments and in-Vivo Animal Models, and Their Possible Relevance for Clinical Applications. Evidence-Based Complementary and Alternative Medicine, 2, 59-67. http://dx.doi.org/10.1093/ecam/neh058

[4] Jiang,Q. L., Zhang, S., Tian, M., Zhang, S.Y., Xie, T., Chen, D.Y., Chen, Y.J., He, J., Liu, J., Ouyang, L. and Jiang, X. (2015) Plant Lectins, from Ancient Sugar-Binding Proteins to Emerging Anti-Cancer Drugs in Apoptosis and Autophagy. Cell Proliferation, 48, 17-28. http://dx.doi.org/10.1111/cpr.12155

[5] Gonzalez de Mejía, E. and Prisecaru, V.I. (2005) Lectins as Bioactive Plant Proteins: A Potential in Cancer Treatment. Critical Reviews in Food Science and Nutrition, 45, 425-445. http://dx.doi.org/10.1080/10408390591034445

[6] Nagre, N.N., Chachadi, V.B., Eligar, S.M., Shubhada, C., Pujari, R., Shastry, P., Swamy, B.M. and Inamdar, S.R. (2010) Purification and Characterization of a Mitogenic Lectin from Cephalosporium, a Pathogenic Fungus Causing Mycotic Keratitis. Biochemistry Research International, 2010, Article ID: 854656. http://dx.doi.org/10.1155/2010/854656

[7] Sharon, N. and Lis, H. (2004) History of Lectins: From Hemagglutinins to Biological Recognition Molecules. Glycobiology, 14, 53R-62R. http://dx.doi.org/10.1093/glycob/cwh122

[8] Christian, B., Thomas, J.B., Melissa, W., de Graaf, A.M.A., van Delft, F.L. den Brok, M.H. and Adema, G.J. (2013) Targeting Aberrant Sialylation in Cancer Cells Using a Fluorinated Sialic Acid Analog Impairs Adhesion, Migration, and in Vivo Tumor Growth. Molecular Cancer Therapeutics, 12, 1935-1946. http://dx.doi.org/10.1158/1535-7163.MCT-13-0279

[9] Lam, S.K. and Ng, T.B. (2011) Lectins: Production and Practical Applications. Applied Microbiology Biotechnology, 89, 45-55. http://dx.doi.org/10.1007/s00253-010-2892-9

[10] Oliveira, C., Nicolau, A., Teixeira, J.A. and Domingues, L. (2011) Cytotoxic Effects of Native and Recombinant Frutalin, a Plant Galactose-Binding Lectin, on Hela Cervical Cancer Cells. Journal of Biomedicine and Biotechnology, 2011, Article ID: 568932. http://dx.doi.org/10.1155/2011/568932

[11] Poiroux G., Pitié, M., Culerrier, R., Ségui, B., Van Damme, E.J.M., Peumans, W.J., Bernadou, J., Levade, T., Rougé, P., Barre, A. and Benoist, H. (2011) Morniga G: A Plant Lectin as an Endocytic Ligand for Photosensitizer Molecule Targeting Toward Tumor-Associated T/Tn Antigens. Photochemistry and Photobiology, 87, 370-377. http://dx.doi.org/10.1111/j.1751-1097.2010.00858.x

[12] Mahalingam, A., Geonnotti, A.R., Balzarini, J. and Kiser, P.F. (2011) Activity and Safety of Synthetic Lectins Based on Benbenzoboroxole-Functionalized Polymers for Inhibition of HIV Entry. Molecular Pharmaceutics, 8, 2465-2475. http://dx.doi.org/10.1021/mp2002957

[13] Koharudin, L.M. and Gronenborn, A.M. (2014) Antiviral Lectins as Potential HIV Microbicides. Current Opinion in Virology, 7, 95-100. http://dx.doi.org/10.1016/j.coviro.2014.05.006

[14] Liu, Z., Luo, Y., Zhou, T.T. and Zhang, W.Z. (2013) Could Plant Lectins Become Promising Anti-Tumor Drugs for Causing Autophagic Cell Death? Cell Proliferation, 46, 509-515.

[15] Randy, C.F., Cheung, H., Leung, H., Pan, W.L. and Ng, T.B. (2013) A Calcium Ion-Dependent Dimeric Bean Lectin with Antiproliferative Activity toward Human Breast Cancer MCF-7 Cells. Protein Journal, 32, 208-215. http://dx.doi.org/10.1007/s10930-013-9477-2

[16] Li, W.W., Yu, J.Y., Xu, H.L. and Bao, K.K. (2011) Concanavalin A: A Potential Anti-Neoplastic Agent Targeting 
Apoptosis, Autophagy and Anti-Angiogenesis for Cancer Therapeutics. Biochemical and Biophysical Research Communications, 414, 282-286. http://dx.doi.org/10.1016/j.bbrc.2011.09.072

[17] Fang, E.F., Lin, P., Wong, J.H., Tsao, S.W. and Ng, T.B. (2010) A Lectin with Anti-HIV-1 Reverse Transcriptase, Antitumor And Nitric Oxide Inducing Activities From Seeds of Phaseolus vulgaris Cv. Extralong Autumn Purple Bean. Journal Agricultural Food Chemistry, 58, 2221-2229. http://dx.doi.org/10.1021/jf903964u

[18] Lima, R.F., Criddle, D.N., Soares, P.M.G., Ribeiro, S.P., Cavada, B.S., Nascimento, K.S., Sampaio, A.H. and Assreuy, A.M.S. (2010) Bryothamnion seaforthii Lectin Relaxes Vascular Smooth Muscle: Involvement of Endothelium and NO Synthase. Protein and Peptide Letters, 17, 305-310. http://dx.doi.org/10.2174/092986610790780332

[19] Liu, B., Bian, H.J. and Bao, J.K. (2010) Plant Lectins: Potential Antineoplastic Drugs from Bench to Clinic. Cancer Letters, 287, 1-12. http://dx.doi.org/10.1016/j.canlet.2009.05.013

[20] Swanson, M.D., Winter, H.C., Goldstein, I.J. and Markovitz, D.M. (2010) A Lectin Isolated from Bananas Is a Potent Inhibitor of HIV Replication. Journal of Biological Chemistry, 285, 8646-55. http://dx.doi.org/10.1074/jbc.M109.034926

[21] Raja, S.B., Murali, M.R., Kumar, N.K. and Devaraj, S.N. (2011) Isolation and Partial Characterization of a Novel Lectin from Aegle marmelos Fruit and Its Effect on Adherence and Invasion of Shigellae to HT29 Cells. PLoS ONE, 6, e16231-e16231. http://dx.doi.org/10.1371/journal.pone.0016231

[22] Ynalvez, R.A., Fuentes, L.M. and Sanchez, C.V. (2011) Comparison and Temperature Study of Lectin Activities in Texas Live Oak (Quercus fusiformis) Crude Extracts. Journal of Plant Science, 6, 124-134. http://dx.doi.org/10.3923/jps.2011.124.134

[23] Chrispeels, M.J. and Raikhel, N.V. (1991) Lectins, Lectin Genes, and Their Role in Plant Defense. Plant Cell, 3, 1-9. http://dx.doi.org/10.1105/tpc.3.1.1

[24] Xiao, X., He, H., Ding, X., Yang,Q., Liu, X., Liu, S., Rang, J., Wang, T., Zuo, M. and Xia, L. (2015) Purification and Cloning of Lectin that Induce Cell Apoptosis from Allium chinense. Phytomedicine, 22, 238-244. http://dx.doi.org/10.1016/j.phymed.2014.12.004

[25] Silvia, M.C.C., Santana, L.A., Mentele, R., Ferreiraa, R.S., de Miranda, A., Silva-Luccac, R.A., Sampaioa, M.U., Correiad, M.T.S. and Oliva, M.L.V. (2012) Purification, Primary Structure and Potential Functions of a Novel Lectin from Bauhinia forficata Seeds. Process Biochemistry, 47, 1049-1059. http://dx.doi.org/10.1016/j.procbio.2012.03.008

[26] Bashir, H., Khan, T., Masood, A. and Hamid, R. (2010) Isolation, Purification and Characterization of a Lectin from a Local Kashmiri Variety of Soybean (Glycine Max). Asian Journal Biochemistry, 5, 145-153. http://dx.doi.org/10.3923/ajb.2010.145.153

[27] Gomes, F.S., Procópio, T.F., Lima, T.A., Napoleão, T.H., Coelho, L.C.B. and Paiva, P.M.G. (2010) Isolation and Antimicrobial Activity of Lectin from Schinus terebinthifolius Leaves. Journal of Biotechnology, 150, 453. http://dx.doi.org/10.1016/j.jbiotec.2010.09.661

[28] Laija, S.N., Mahesh, S., Smitha, L.S. and Remani, P. (2010) Isolation and Partial Characterization of Two Plant Lectins. Current Research Journal of Biological Sciences, 2, 232-237. http://www.maxwellsci.com/print/crjbs/v2-232-237.pdf

[29] Silva, M.C., Corrêa, A.D., Donizete dos Santos, C., Marcos, F.C.A. and Patto de Abreu, C.M. (2010) Partial Purification of Leaf Lectin from Manihot esculenta and Screening Its Fungicidal Activity. Journal of Agricultural Biotechnology and Sustainable Development, 2, 136-141. http://www.isabb.academicjournals.org/article/article1379332438_Silva\%20et\%20al.pdf

[30] Lin, P., Ye, X. and Ng, T. (2008) Purification of Melibiose-Binding Lectins from Two Cultivars of Chinese Black Soybeans. Acta Biochimica et Biophysica Sinica, 40, 1029-1038. http://dx.doi.org/10.1111/j.1745-7270.2008.00488.x

[31] Chen, H.P. and Xu, L.L. (2005) Isolation and Characterization of a Novel Chitosan-Binding Protein from Non-Heading Chinese Cabbage Leaves. Journal of Integrative Plant Biology, 47, 452-456. http://dx.doi.org/10.1111/j.1744-7909.2005.00022.x

[32] Kaur, A., Singh, J., Kamboj, S.S., Sexana, A.K., Pandita, R.M. and Shamnugavel, M. (2005) Isolation of an N-AcetylD-Glucosamine Specific Lectin from the Rhizomes of Arundo donax with Antiproliferative Activity. Phytochemistry, 66, 1933-1940. http://dx.doi.org/10.1016/j.phytochem.2005.06.026

[33] Almanza, M., Vega, N. and Pérez, G. (2004) Isolating and Characterizing a Lectin from Galactialindenii Seeds That Recognizes Blood Group H Determinants. Archives of Biochemistry and Biophysics, 429, 180-190. http://dx.doi.org/10.1016/j.abb.2004.06.010

[34] Kuku, A., Odekanyin, O., Adreniran, K., Adewusi, M. and Olonade, T. (2009) Purification of a Mannose/GlucoseSpecific Lectin with Antifungal Activity from Pepper Seeds (Capsicum annuum). African Journal of Biochemistry Research, 3, 272-278.

http://www.researchgate.net/publication/228472330_Purification_of_a_mannoseglucose-specific_lectin_with_antifung 
al_activity_from_pepper_seeds_\%28Capsicum_annuum\%29

[35] Occeña, I.V., Mojica, E.R.E. and Merca, F.E. (2007) Isolation and Partial Characterization of a Lectin from the Seeds of Artocarpus camansi Blanco. Asian Journal of Plant Science, 6, 757-764. http://dx.doi.org/10.3923/ajps.2007.757.764

[36] Adenike, K. and Eretan, O.B. (2004) Purification and Partial Characterization of a Lectin from the Fresh Leaves of Kalanchoe crenata (Andr.) Haw. Journal of Biochemistry and Molecular Biology, 37, 229-233. http://dx.doi.org/10.5483/BMBRep.2004.37.2.229

[37] Simpson, B.J. (1999) A Field Guide to Texas Trees. Lone Star Books, Houston.

[38] Tull, D. and Miller, G.O. (1999) A Field Guide to Wildflowers, Trees and Shrubs of Texas. Lone Star Books, Houston.

[39] Bradford, M.M. (1976) A Rapid and Sensitive Method for the Quantitation of Microgram Quantities of Protein Utilizing the Principle of Protein-Dye Binding. Analytical Biochemistry, 72, 248-254. http://dx.doi.org/10.1016/0003-2697(76)90527-3

[40] Naeem, A., Saleemuddin, M. and Hasan Khan, R. (2007) Glycoprotein Targeting and Other Applications of Lectins in Biotechnology. Current Protein and Peptide Science, 8, 261-271. http://dx.doi.org/10.2174/138920307780831811

[41] Muramoto, K., Kado, R., Takei, Y. and Kamiya, H. (1991) Seasonal Changes in the Multiple Lectin Compositions of the Acorn Barnacle Megabalanus rosa as Related to Ovarian Development. Comparative Biochemistry and Physiology, 98, 603-607.

[42] Nsimba-Lubaki, M. and Peumans, W.J. (1986) Seasonal Fluctuations of Lectins in Barks of Elderberry (Sambucus nigra) and Black Locust (Robinia pseudoacacia). Plant Physiology, 80, 747-751. http://dx.doi.org/10.1104/pp.80.3.747

[43] Costa, R.M.P., Vaz, A.F.M., Oliva, M.L.V., Coelho, L.C.B., Correia, M.T.S. and Carneiro-da-Cunha, M.G. (2010) A New Mistletoe Phthirusa pyrifolia Leaf Lectin with Antimicrobial Properties. Process Biochemistry, 45, 526-533. http://dx.doi.org/10.1016/j.procbio.2009.11.013

[44] Drickamer, K. (1995) Multiplicity of Lectin-Carbohydrate Interactions. Nature Structural Biology, 2, 437-439. http://dx.doi.org/10.1038/nsb0695-437

[45] Drickamer, K. and Taylor, E. (2002) Glycan Arrays for Functional Glycomics. Genome Biology, 3, Reviews1034.1Reviews1034.4. http://genomebiology.com/2002/3/12/reviews/1034

[46] Khan, M.M.H., Rahman, A.T.M., Uddin, M.S., Khatun, S., Pervin, F. and Absar, N. (2008) Purification and Characterization of Lectins from Jute (Chorchorus olitorius) Leaves. Journal of the Chinese Chemical Society, 55, 1171-1177. http://dx.doi.org/10.1002/jccs.200800173

[47] Wu, A.M., Lisowska, E., Duk, M. and Yang, Z. (2009) Lectins as Tools in Glycoconjugate Research. Glycoconjugate Journal, 26, 899-913. http://dx.doi.org/10.1007/s10719-008-9119-7

[48] Kusui, K. and Takasaki, S. (1998) Structural Study of N-Linked Sugar Chains of Sheep Erythrocyte Membrane Glycoproteins. Glycoconjugate Journal, 15, 3-10. http://dx.doi.org/10.1023/A:1006967614009

[49] Shibuya, N., Goldstein, I.J., Van Damme, E.J.M. and Peumans, W.J. (1988) Binding Properties of a Mannose-Specific Lectin from the Snowdrop (Galanthus nivalis) Bulb. Journal of Biological Chemistry, 263, 728-734. http://www.jbc.org/content/263/2/728

[50] Yagi, F., Iwaya, T., Haraguchi, T. and Goldstein, I.J. (2002) The Lectin from Leaves of Japanese Cycad, Cycas revoluta Thunb. (Gymnosperm) Is a Member of the Jacalin-Related Family? European Journal of Biochemistry, 269, 4335-4341. http://dx.doi.org/10.1046/j.1432-1033.2002.03127.x

[51] Loris, R. (2002) Principles of Structures of Animal and Plant Lectins. Biochimica et Biophysica Acta, 1572, $198-208$. http://dx.doi.org/10.1016/S0304-4165(02)00309-4

[52] Sacchettini, J.C., Baum, L.G. and Brewer, C.F. (2001) Multivalent Protein-Carbohydrate Interactions. A New Paradigm for Supermolecular Assembly and Signal Transduction. Biochemistry, 40, 3009-3015. http://dx.doi.org/10.1021/bi002544j

[53] Konozy, E.H.E., Mulay, R., Faca, V., Ward, R.J., Greene, L.J., Roque-Barriera, M.C., Sabharwal, S. and Bhide, S.V. (2002) Purification, Some Properties of a D-Galactose-Binding Leaf Lectin from Erythrina indica and Further Characterization of Seed Lectin. Biochimie, 84, 1035-1043. http://dx.doi.org/10.1016/S0300-9084(02)00003-2

[54] Moreira, R.A., Castelo-Branco, C.C., Monteiro, A.C.O., Tavares, R.O. and Beltramini, L.M. (1998) Isolation and Partial Characterization of a Lectin from Artocarpus incisa L. Seeds. Phytochemistry, 47, 1183-1188. http://dx.doi.org/10.1016/S0031-9422(97)00753-X

[55] Han, J.W., Jung, M.G., Kim, M.J., Yoon, K.S., Lee, K.P. and Kim, G.H. (2010) Purification and Characterization of a D-Mannose Specific Lectin from the Green Marine Alga, Bryopsis plumosa. Phycology Research, 58, 143-150. http://dx.doi.org/10.1111/j.1440-1835.2010.00572.x

[56] Ugwu, S.O. and Apte, S.P. (2004) The Effect of Buffers on Protein Conformational Stability. Pharmaceutical Tech- 
nology, 28, 86-108.

[57] Utarabhand, P. and Akkayanont, P. (1995) Purification of a Lectin from Parkiajavanica Beans. Phytochemistry, 38, 281-285. http://dx.doi.org/10.1016/0031-9422(94)00550-D

[58] Sureshkumar, T. and Priya, S. (2012) Purification of a Lectin from M. rubra Leaves Using Immobilized Metal Ion Affinity Chromatography and Its Characterization. Applied Biochemistry and Biotechnology, 168, 2257-2267. http://dx.doi.org/10.1007/s12010-012-9934-y

[59] Salles, H.O., Vasconcelos, I.M., Santos, L.F.L., Oliveira, H.D., Costa, P.P., Nascimento, N.R.F., Santos, C.F., Sousa, D.F., Jorge, A.R.C., Menezes, D.B., Monteiro, H.S.A., Gondim, D.M.F. and Oliveira, J.T.A. (2011) Towards a Better Understanding of Ipomoea asarifolia Toxicity: Evidence of the Involvement of a Leaf Lectin. Toxicon, 58, 502-508. http://dx.doi.org/10.1016/j.toxicon.2011.08.011

[60] Park, W.B., Han, S.K., Lee, M.Y. and Han, K.H. (1997) Isolation and Characterization of Lectins from Stem and Leaves of Korean Mistletoe (Viscum album var. coloratum) by Affinity Chromatography. Archives of Pharmacal Research, 20, 306-312. http://dx.doi.org/10.1007/BF02976191

[61] Hung, L.D., Hori, K., Nang, H.Q., Kha, T. and Hoa, L.T. (2009) Seasonal Changes in Growth Rate, Carrageenan Yield and Lectin Content in the Red Alga Kappaphycus alvarezii Cultivated in Camranh Bay, Vietnam. Journal of Applied Phycology, 21, 265-272. http://dx.doi.org/10.1007/s10811-008-9360-2

[62] Gonzalez de Mejía, E., Maldonado, S.H.G., Gallegos, J.A.A., Camacho, R.R., Rodriguez, E.R., Hernandez, J.L.P., Chavira, M.M.G., Castellanos, J.Z. and Kelly, J.D. (2003) Effect of Cultivar and Growing Location on the Trypsin Inhibitors, Tannins, and Lectins of Common Beans (Phaseolus vulgaris L.) Grown in the Semiarid Highlands of Mexico. Journal of Agricultural Food Chemistry, 51, 5962-5966. http://dx.doi.org/10.1021/jf030046m

[63] United States Department of Agriculture (1985) Natural Resources Conservation Service,. Texas Online Soil Survey Manuscript, Webb County.

[64] De Souza Cândido, E., Pinto, M.F.S., Pelegrini, P.B., Lima, T.B., Silva, O.N., Pogue, R., Grossi-de-Sá, M.F. and Franco, O.L. (2011) Plant Storage Proteins with Antimicrobial Activity: Novel Insights into Plant Defense Mechanisms. Federation of American Societies for Experimental Biology Journal, 25, 3290-3305. http://dx.doi.org/10.1096/fj.11-184291

[65] Lerouge, P., Roche, P., Faucher, C., Malliet, F., Truchet, G., Promé, J.C. and Denarié, J. (1990) Symbiotic Host Specificity of Rhizobium meliloti Is Determined by a Sulphated and Acylated Glucosamine Oligosaccharide Signal. Nature, 344, 781-784. http://dx.doi.org/10.1038/344781a0

[66] Vandenborre, G., Smagghe, G. and Van Damme, E.J.M. (2011) Plant Lectins as Defense Proteins against Phytophagous Insects. Phytochemistry, 72, 1538-1550. http://dx.doi.org/10.1016/j.phytochem.2011.02.024

[67] Ratanapo, S., Ngamjunyaporn, W. and Chulavatnatol, M. (2001) Interaction of a Mulberry Leaf Lectin with a Phytopathogenic Bacterium, P. syringaepvmori. Plant Science, 160, 739-744. http://dx.doi.org/10.1016/S0168-9452(00)00454-4

[68] Ayouba, A., Causse, H., Van Damme, E.J.M. , Peumans, W.J., Bourne, Y., Cambillau, C. and Rougé, P. (1994) Interactions of Plant Lectins with the Components of the Bacterial Cell Wall Peptidoglycan. Biochemical Systematics and Ecology, 22, 153-159. http://dx.doi.org/10.1016/0305-1978(94)90005-1

[69] Albuquerque, L.P., Santana, G.M.S., Melo, A.M.A., Coelho, L.C.B., Silva, M.V. and Paiva, P.M.G. (2010) Deleterious Effects of Microgramma vaccinifolia Rhizome Lectin on Fusarium Species and Artemiasalina. Journal of Biotechnology, 150, S453. http://dx.doi.org/10.1016/j.jbiotec.2010.09.662

[70] Hossain, M.A., Maiti, M.K., Basu, A., Sen, S., Ghosh, A.K. and Sen, S.K. (2006) Transgenic Expression of Onion Leaf Lectin Gene in Indian Mustard Offers Protection against Aphid Colonization. Crop Science, 46, 2022-2032. http://dx.doi.org/10.2135/cropsci2005.11.0418

[71] Yildirim, I., Turhan, H. and Özgen, B. (2010) The Effects of Head Rot Disease (Rhizopus stolonifer) on Sunflower Genotypes at Two Different Growth Stages. Turkish Journal of Field Crops, 15, 94-98. http://www.field-crops.org/assets/pdf/product513202a2be6f4.pdf

[72] Wong, J.H. and Ng, T.B. (2005) Isolation and Characterization of a Glucose/Mannose/Rhamnose-Specific Lectin from the Knife Bean Canavalia gladiata. Archives of Biochemistry and Biophysics, 439, 91-98. http://dx.doi.org/10.1016/j.abb.2005.05.004

[73] Ye, X.Y., Ng, T.B., Tsang, P.W.K. and Wang, J. (2001) Isolation of a Homodimeric Lectin with Antifungal and Antiviral Activities from Red Kidney Bean (Phaseolus vulgaris) Seeds. Journal of Protein Chemistry, 20, 367-375. http://dx.doi.org/10.1023/A:1012276619686

[74] Melo, F.R., Benevides, N.M.B., Pereira, M.G., Holanda, M.K., Mendes, F.N.P., Oliveira, S.R.M., Freitas, A.L.P. and Silva, L.M.C. (2004) Purification and Partial Characterization of a Lectin from the Red Marine Alga Vidalia obtusiloba C. Agardh. Brazilian Journal of Botany, 27, 263-269. http://dx.doi.org/10.1590/S0100-84042004000200006 